\title{
THE PHYSIOLOGY AND GENETIC SIGNIFICANCE OF ENZYMATIC ADAPTATION $^{1}$
}

\author{
S. SPIEGELMAN \\ Washington University School of Medicine, \\ St. Louis, Missouri

\section{THE PHENOMENON OF ADAPTATION}

Wortmann (1882) showed that certain bacterial species could produce nylase only when grown in the presence of starch. Since these early observations many more of a similar nature have been made. The bacteriological literature in particular contains innumerable instances of so-called "training" phenomena of the most varied kinds. Recent reviews by Karström ('38), Yudkin ('38), Rahn ('38), Stephenson ('39), Linderstrom-Lang ('40), Dubos ('40), and Gale ('43) summarize the available data.

The essentials of the phenomenon may be stated in the following terms: a population of cells placed in contact with some substrate acquires, after the lapse of some time, the enzymes necessary to metabolize the added substrate. The removal of the substrate leads to the disappearance of the enzyme system it evoked.

Karström ('38) designated as "adaptive" those enzymes which are produced as a specific response to the presence of the homologous substrate. Such enzymes were differentiated from the "constitutive" ones which are always formed by the cells of a given species, regardless of the presence or absence of their homologous substrates.

Because of its convenience, Karström's terminology has been widely adopted. In recent years, however, it has become increasingly clear that it is not adequate for the description of the facts. In the first place, the classification raises the obvious difficulty that the ease with which a given enzyme is detected in low amounts will determine the category in which it is placed. In addition, enzymes which have been labeled constitutive undergo wide fluctuations in the presence and absence of their substrate. Thus, the invertase content of $B$. coli rises to 452 (Stephenson, '39) in the presence of sucrose and falls to values lying 12.4 and 39 in its absence. Again the $\mathrm{Q}_{\text {glucose }}$ value of $B$. coli is about 1,000 for organisms grown in the presence of glucose and about 190 for those grown in lactate medium (Stephenson and Gale, '37). In all carefully examined instances where enzymesubstrate relations are known, substrate has stimulated or stabilized its enzyme. The only claim for independence of enzyme level from its substrate was made by Quastel ('37), who reported that glucose stimulated urease formation whereas urea suppressed it. However, Epps and Gale ('42) reinvestigated the problem and showed that the differences Quastel observed depended on the fact that ex-

\footnotetext{
${ }^{1}$ Certain of the investigations reported here were aided by a grant from the Penrose Fund of the American Philosophical Society. Grateful acknowledgment is also made to the Department of Zoology of Washington University for the facilities so generously placed at the disposal of the author.
} 
traction was done in the absence of substrate. They found that growth in the presence of urea stabilized the urease content of cells.

While exceptions may be found by future study, there does exist a relatively large group of well-defined enzyme systems which respond positively to their specific substrates. In the case of the "adaptive" enzymes, the response is marked and the enzymes fall to zero or near zero levels in the absence of substrate. These enzymes seem to differ from the constitutive ones solely in their relatively greater instability in the absence of substrate. It seems questionable, from this point of view, whether classification into "adaptive" and "constitutive", implying as these terms do a difference in origin and function, is fruitful or even valid. This same point of view implies that enzymatic "adaptations" are but quantitatively exaggerated instances of a more general phenomenon resulting from the effects of substrates on the synthesis and stability of their enzymes.

While we shall in the present discussion use the term "adaptive" in connection with enzyme formation, it should be emphasized that this is not meant to imply the de novo induction by substrate of the enzyme concerned. The term is used here to describe the situation in which an enzyme responds by increasing in the presence of its substrate and decreasing in its absence.

From the standpoint of genetics, enzymatic adaptation has several interesting possibilities. Thus far, attacks on the problem of the nature of gene action has had to depend, for the most part, on the study of the final end products of enzymatic activity. It has generally been assumed that genes determine phenotype by virtue of their control of enzymatic constitution. If this be true, the process of adaptation presents an unique opportunity for examining certain details of gene action. In particular, it is reasonable to hope that such studies could delineate the nature of the control exercised by genes over enzyme activity. It is the purpose of this paper to present some data bearing on this problem.

We shall confine our attention to galactozymase and melibiozymase activities and their variations in yeast cells.

\section{BIOLOGICAL MECHANISMS OF POPULATIONAL ADAPTATIONS}

Large numbers of individuals are always involved in adaptation experiments, and it is inevitable that attempts to elucidate further the biological nature of these modifications encounter a basic problem common to all studies of physiological changes in large populations. A comparative biochemical study of large populations always involves over-all populational characteristics. This necessarily introduces difficulties into the interpretations of any observed changes in physiological properties. The mechanisms available to an individual cell for adapting itself to an environmental change are limited by its genome and the physiological flexibility permitted by its particular degree of specialization. When, however, the adaptation of a population of cells is being considered, there must be added to the physiological pliability of its members the genetic plasticity of the group in terms of the numbers and kinds of variants it is capable of producing. 
Because of this composite nature of populational adaptability, it is clear that in any given case the same end result can be obtained by any one of the following mechanisms: (1) The natural selection of existent variants with the desired characteristics from a genotypically heterogeneous population; (2) induction of a new (as far as measurements are concerned) enzyme by the substrate in all the members of a homogeneous population; and ( 3 ) a combination of natural selection and the action of mechanism (2) on those selected.

It was difficult to resolve these questions with bacteria since genetic control over their populations is not attainable. In two instances, however, a decision on the biological mechanism involved was possible. Lewis ('34) showed that the ability of so-called "trained strains" of B. coli to ferment lactose originated through the natural selection of a spontaneous variant which was always present in the original culture in the ratio of about $1: 1 \times 10^{5}$. Stephenson and Stickland, ('33) were able to demonstrate the formation of hydrogenlyase in the presence of formate in non-dividing cultures of $B$. coli.

It is clear that a considerable advantage would be gained if it were possible to study this phenomenon with microorganismic populations whose genetics could be controlled. Aside from the obvious possibility of examining the genetics of the process, the study of its physiology could be enormously simplified. Reproducibility of the measurements would thus be assured and the complications of natural selection, which are always present when dealing with genetically heterogeneous material, could be avoided. The opportunity of using genetically controllable matcrial was provided by the fundamental work of Winge and Laustsen ('37, '38, '39a), in Denmark, and the Lindegrens ('43a, b, c), in this country, on the genetics and life cycle of the yeasts.

\section{THE GENETIC CONTROL OF GALACTOZYMASE FORMATION IN YEAST POPULATIONS}

Dienert ('00) was one of the first to describe a well-defined example of populational adaptation in the yeasts. He showed that suspensions of yeast cells could acquire the enzymatic apparatus necessary to ferment galactose when placed in contact with it. Since its discovery by Dienert this particular problem has been investigated by numerous workers. Armstrong ('05) confirmed Dienert's findings and further found that some yeasts were incapable of acquiring this physiological property, no matter how long they were cultured in the presence of galactose. Slator ('08) showed that those yeasts capable of fermenting galactose possess this ability only after they had been acclimatized by culture in its presence. No yeast he investigated was able to ferment this hexose immediatley upon being introduced to a medium containing it. There was always an induction period of variable length connected with the acquisition of this property.

Several attempts were made to decide whether natural selection or a direct interaction between the galactose and the cytoplasm was involved in the appearance of galactozymase. Sohngen and Coolhas ('24) grew their yeast cultures at 
$30^{\circ} \mathrm{C}$. and measured enzymatic activity at $38^{\circ} \mathrm{C}$. to avoid cell division during the measurement of $\mathrm{CO}_{2}$ evolution. They concluded, from their experiments, that the production of galactozymase parallels the formation of new cells. In addition, they confirmed Kluyver's ('14) findings that at $38^{\circ} \mathrm{C}$., at which temperature cell division is completely inhibited, no adaptation takes place. Other investigators also tried to obtain adaptation in the absence of cell division, since this would clearly exclude the operation of natural selection as a causal agent in effecting the change. Euler and Nilsson ('25) and later Euler and Jansson ('27), in a more thorough investigation, tried, without success, to adapt yeast in the presence of 0.5 per cent phenol to inhibit cell division. The failure of the abovementioned authors to find adaptation in the complete absence of cell division cannot be taken as conclusive evidence that no such phenomenon could exist. Especially is this true in those cases where suppression was obtained by such agents as heat or cellular poisons. It is not unlikely that in cultures where this "ideal" had been reached, the physiological state of the cells was such that their ability to synthesize new enzymes had been lost along with their ability to divide.

Stephenson and Yudkin ('36) concluded from their experiments that the production of galactozymase in yeast cultures need not involve the formation of new cells. This conclusion was based on the observation that the ability to evolve $\mathrm{CO}_{2}$ anaerobically, from a medium containing galactose, was acquired in a period when the total and viable count remained constant. These findings were apparently in direct contradiction with those of previous workers and in particular of Sohngen and Coolhaas ('24).

Before undertaking any detailed study of the physiology of this adaptation, it was clearly necessary to resolve this difficulty. It is evident from the nature of the problem of populational adaptability that one of the crucial problems at issue is the phenotypic homogeneity or heterogeneity of the starting population. The possibility of attacking the problem from this point of view was provided by the use of known haploid and diploid strains, thus permitting genetic control over the populations being studied.

Two strains of Saccharomyces cerevisiae, Db23B and LK2G12, both of which could acquire the ability to ferment galactose when grown in its presence, were selected for study. Strain Db23B, which was known to be a haploid and therefore genetically unstable, was shown (Spiegelman, Lindegren and Hedgecock, '44) to be phenotypically heterogeneous with respect to galactose fermentation. Some individuals in populations derived from this strain could not adapt to ferment galactose, whereas others could. Strain LK2G12, on the other hand, which was known to be diploid, was uniformly homogeneous in that all of its individuals were able to acquire the capacity for the fermentative utilization of galactose on standing in contact with the sugar. The adaptive behavior of these two strains followed what would be expected from the data obtained on their phenotypic 
characteristics. Populations of $\mathrm{Db} 23 \mathrm{~B}$, starting with a low percentage of the fermenting type, could increase their enzymatic activity only through the mechanism of cell division and the subsequent selection in favor of the galactose fermenters. It was shown (Spiegelman and Lindegren, '44) that the kinetics of adaptation by $\mathrm{Db} 23 \mathrm{~B}$ populations were in agreement with the natural selection hypothesis. Using the appropriate strains, experiments were performed which sought to duplicate the findings reported by Sohngen and Coolhaas and those reported by Stephenson and Yudkin. The results are summarized in fig. 1.

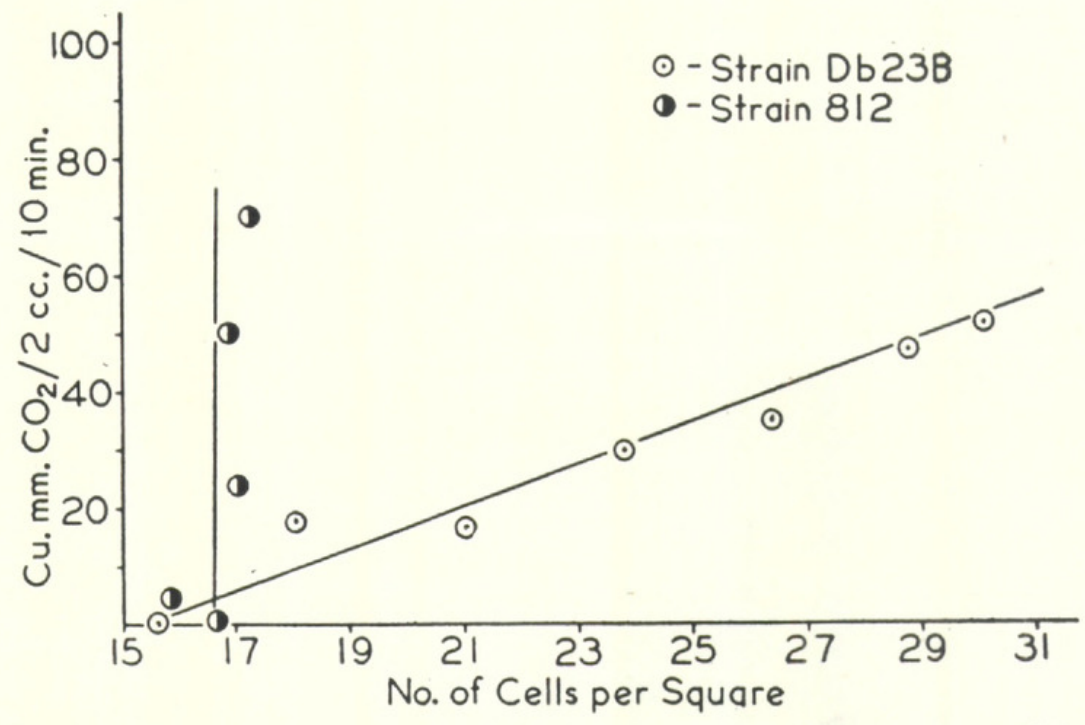

Fig. 1. A comparison of the variation of enzyme activity (expressed as rate of anaerobic $\mathrm{CO}_{2}$ production) and the number of cells in adapting cultures of haploid (Db23B) and diploid (812) strains.

It is strikingly apparent that populations of the haploid strain, $\mathrm{Db} 23 \mathrm{~B}$, in crease their enzyme activity by virtue of the new cells arising during the experimental period, and agree with Sohngen and Coolhaas. On the other hand, the measured activity of the diploid 812 population was, in the period examined, virtually independent of cell number. This strain was able to increase its activity from zero to an activity level of 70 , while maintaining its population at the same density. The results with this strain thus confirm Stephenson and Yudkin.

From these results it is clear that the contradiction noted is only an apparent one and is probably due to the differences in the genetic background and phenotypic constitution of the strains employed. The conclusion may also be drawn that it is futile to attempt to decide, as some previous authors have tried to do, between the "natural selection" hypothesis and the one of "direct cytoplasmic interaction", as the explanation for the production of some one adaptive enzyme. The particular biological mechanism involved in the production of a given enzyme or enzyme system in a population of cells is a characteristic of the strain being examined, rather than of the enzyme system itself. Such questions cannot be answered without referring to the genetic background and stability of the popula- 
tion being studied. It is also evident that such strains as LK2G12 and 812 possess three important characteristics of immense value for investigations into the physiology of enzyme synthesis, namely, (1) a genome which permits the synthesis of the enzyme being studied; (2) the genetic stability to insure reproducibility of the physiological characteristics of the populations, and (3) the ability to adapt without cell division.

\section{THE GENETIC BASIS OF INABILITY TO ADAPT TO GALACTOSE FERMENTATION}

From the earliest investigations by Armstrong ('05) and Kluyver ('14), the existence of unadaptable yeasts was noted. Subsequent investigations have uncovered many more. As may be seen from a perusal of Stelling-Dekker's ('31) monograph on the sporogenous yeasts, examples of non-fermenters of galactose exist in all the genera.

It did not seem improbable, in view of our experience with $\mathrm{Db} 23 \mathrm{~B}$, that the failure to adapt certain of the strains might be due to incomplete utilization of their mutational potentialities. Thus, a non-sporulating population of diploids or one in which some other mechanism existed for the suppression of the haplophase would be unlikely to gain a new character or lose an old one by mutation. This suggested the possibility of attempting to adapt strains, which had been previously labeled as non-fermenters of galactose, by encouraging the production of haploids and thus disturbing the genetic stability of the population. From the point of view of the life cycle of the yeast, this could usually be accomplished by inducing heavy sporulation and allowing germination to occur, thus releasing haploid cells into the population.

Such experiments were performed (Spiegelman and Lindegren, '45) with three yeast types, Schizosaccharomyces Pombe, Scbizosaccharomyces octosporus, and Saccharomycodes Ludwigii. All three were investigated by Armstrong ('05), who concluded that they were incapable of adaptation to galactose fermentation. In addition to the fact that they have been studied more thoroughly than other non-fermenters of galactose, they were selected for another advantage, which is of some importance from a comparative point of view. Sch. Pombe can, without any difficulty, exist in the haplophase. This is not true of Sch. octosporus and still less so for Saccharomycodes Ludwigii.

The mechanisms of suppression of the haplophase in the latter two strains differ. While Sch. octosporus sporulates with ease, the haploids which result from the germination fuse rapidly to produce diploid cells. When spores from fourand eight-spored asci from the stock culture were planted, they all grew and every single-spore culture thus obtained sporulated on the agar in less than 48 hours. The further spore analysis of this strain indicates that the diploid stock culture was completely homozygous and that, unlike S. cerevisiae, the production of viable spores apparently does not depend on the prëexistence of a heterozygous nucleus. The sporulation of single-spore cultures was never observed in the $S$. cerevisiae strains used in the adaptation studies. The fact that it does occur in 
Sch. octosporus is an indication of heavy diploidization which is confirmed by direct microscopic observation. Isolated non-fusing haploid cells are rarely seen in suspensions of single-spore cultures of Sch. octosporus. This process of immediate fusion effectively suppresses the haplophase, and in these cultures genetic variations come mainly from recombinations. This source of variation would obviously not be effective in populations which are homozygous for the recessive.

The suppression mechanism is even more highly developed in Saccharomycodes Ludwigii. Guilliermond ('03) reported that this yeast usually forms four spores without previous conjugation. On germination, however, the spores conjugate within the mother cell, two by two, so that only two vegetative cells emerge from each four-spored ascus. Winge and Laustsen ('39b) confirmed these observations and described the successful isolation of the haplophase by micromanipulative dissection of the ascospore and separation of the four spores before germination. As a result of their examination of the haplophase cultures they concluded that Saccharomycodes Ludwigii was a balanced heterozygote. The net result of the germination mechanism is the almost complete suppression of the haplophase under normal conditions.

When heavily sporulating (20 per cent and above) cultures of Schizosaccharomyces Pombe were seeded into 8 per cent galactose, 2 per cent glucose media, adaptable populations were recovered. The results are summarized in Table I. Exactly similar experiments with Schizosaccharomyces octosporus and Saccharomycodes Ludwigii failed. These failures are understandable in terms of the inability of the latter strains to express the mutational potentialities of their haplophases. It might also be noted that adaptable cultures were never recovered from Sch. Pombe in the absence of heavy sporulation no matter how long contact with galactose was maintained.

It is clear from these experiments that inability to adapt is in some cases due to the genetic stability conferred by diploidy. It may, however, be doubted whether all that is required for populational adaptation is the breakdown of the genetic stability of the unadaptable strain. It is conceivable that the haplophase of a particular strain might not contain within its mutational potentialities the ability to mutate in the direction of, for example, galactose fermentation. That such indeed could be the case was shown by the isolation of three haploid strains (Spiegelman and Lindegren, '45) which could not mutate towards galactose fermentation although kept in contact with the sugar over a four-month period. During this same period they were, however, throwing off numerous physiological and morphological mutants of various kinds.

As was noted by Lindegren ('45), preliminary experiments on hybrids between S. Bayanus and S. cerevisiae clearly indicate a typical genetic control of adaptability and non-adaptability to galactose fermentation. 
TABLE I

ADAPTATION OF SCHIZOSACCHAROMYCES POMBE TO GALACTOSE FERMENTATION

\begin{tabular}{c|c|c}
\hline \hline Experiment & $\begin{array}{c}\text { Origin of heavily sporulating } \\
\text { cultures }(20 \% \text { and above })\end{array}$ & $\begin{array}{c}\text { Days required for } \\
\text { appearance of adaptation }\end{array}$ \\
\hline 1 & 20 -day broth culture \\
2 & 20-day broth culture \\
3 & 24-day agar slant & 8 \\
4 & Gypsum Block & 6 \\
5 & Gypsum Block & 12 \\
7 & Gypsum Block & 2 \\
\hline
\end{tabular}

\section{BIOCHEMICAL ASPECTS OF ADAPTATION}

Before undertaking an analysis of the genetic implications of the phenomenon, there are certain questions it would be desirable to answer as completely as the data allow. These questions would involve, among other things, the existent evidence for enzyme formation, possible biochemical functions of the induced enzymes, and connection of the adaptation with the over-all metabolic activity of the cell.

Implicit in the discussion presented here, as well as in the entire literature of the so-called "adaptive" enzymes, is the assumption that when a cell is placed in contact with some substrate and acquires, during the course of time, the ability to metabolize the added substrate, a new enzyme must have made its appearance. This assumption stems, of course, from the innumerable observations that every metabolic process requires an enzyme. Direct proof that an enzyme is synthesized would involve its isolation from the adapted cells and is not available in any known case of adaptation. Such proof, in any case, would have to be preceded by a determination of the number and functions of the enzymes induced by the substrate. At present the best that can be offered is evidence of enzyme activity in cell extracts after adaptation. In the case of both galactozymase and melibiozymase, sufficient work has been done to remove any reasonable doubt on the question of enzyme involvement in the adaptation. A delayed penetration into the cell can certainly not be invoked as the explanation of the induction period in galactose fermentation. It was shown (Spiegelman, '45a) that galactose actually enters the cell immediately and is metabolized by a purely aerobic mechanism in the preadaptive period before the fermentative enzymes make their appearance. Further, it has been found earlier (Harden and Norris, '10) that yeast juice and maceration extract prepared from adapted yeasts grown on galactose were able to 
ferment galactose. Similar preparations from glucose-grown cultures were inactive. These experiments were repeated and confirmed with our own strains using toluol cytolysates. It is clear from these experiments that something, possessing galactose-fermenting capacity, can be extracted from cells after adaptation which was not there before. Experiments of the same type on cell extracts were performed in adaptations to melibiose fermentation. Here again activity could be demonstrated in the cytolysate only after adaptation was established in the intact cells. It may be noted here that all such extracts were made in the presence of substrate.

Certainly a question of prime importance is the nature of the enzymatic changes necessary for the newly acquired metabolic property. Is a whole new set of enzymes required? Or, is only one or two formed which would transform the sugar into one utilizable by the glucozymase system?

In the case of melibiozymase, it seems most probable that a single enzyme only is formed which splits melibiose into glucose and galactose. An enzyme of this kind has been demonstrated in emulsin preparations by Kuhn ('23), who called it melibiase. Little direct work on this enzyme has as yet been done.

Because of the relative importance of galactose in mammalian physiology, a considerable amount of work has been done on the nature of the enzymatic change which permits a yeast cell to ferment this hexose. Harden and Norris ('10) found that a fermenting mixture of yeast-juice (from an adapted yeast) and galactose reacted with added phosphate in a manner similar to ordinary yeast juice and glucose, although a longer induction period was necessary. The rate of $\mathrm{CO}_{2}$ formation was accelerated, an extra amount of $\mathrm{CO}_{2}$ equivalent to the phosphate added was evolved, and the rate then again became normal. The phosphate was converted into an organic form not precipitable by magnesium citrate mixture. Euler and Jansson ('27) showed that when dried adapted yeasts are washed, they fail to ferment galactose. However, such preparations can be reactivated to galactose by adding the co-enzyme prepared from unadapted yeast. They were thus able to exclude the possibility that adaptation is concerned with the modification of the existent cozymase or the formation of a new one. Nilsson ('43) was able to isolate from the products of the fermentation of galactose by a sample of dried adapted yeast, a diphosphoric ester which, in its elementary analysis and specific rotation, closely resembled the hexosediphosphate formed during the fermentation of glucose, fructose and mannose.

In order to explain the formation of the same diphosphate from galactose as from the normally fermentable sugars, Nilsson ('43) suggests that the fermentation of a hexose involved the splitting of the monophosphate ester into a triose and a triose phosphate ester. This would destroy the spatial specificity of the fourth carbon atom in the galactose molecule and the resulting phosphorylated triose could be built up into fructose diphosphate. If this were true, it would be necessary to postulate the formation of only one enzyme in the adaptation to galactose fermentation. 
It is true that Meyerhof and Lohmann ('34) have shown the existence of an enzyme (zymohexase) in yeast and muscle preparations capable of converting triosemonophosphoric ester into fructose diphosphate. Nevertheless, experimental support for Nilsson's scheme of fermentation is relatively weak. He assumes that the formation of fructose-di-phosphate is an artifact and that the fermentation proceeds from his postulated split of the hexose monophosphate. He bases this on the observation that fructose diphosphate is fermented much more slowly than fructose. However, this can be explained in terms of the classical MeyerhofParnas fermentative scheme on the basis of the unavailability of phosphate acceptors. Thus, Meyerhof and Lohmann ('27) found a $\mathrm{CO}_{2}$ production of only 25 per cent of the calculated values when maceration extract fermented Robison esters. Warburg and Christian ('39) have shown that the partial dephosphyorylation of 1:3-diphosphoglyceric acid to 3-phosphyglyceric acid by the hexokinaseadenosine diphosphate-hexose system may become limiting in the fermentative process.

Cattaneo ('33) has obtained additional evidence pointing to the convergence of the fermentation paths of galactose and glucose by isolating phosphoglyceric acid from the phosphorylated products formed during the fermentation of galactose by preparations of adapted yeast in the presence of added phosphate, acetaldehyde and sodium fluoride. Grant ('35) reinvestigated this problem and confirmed the work of previous investigators on the role of phosphorylations in the metabolism of galactose by adapted yeast. He was able to establish, with some certainty, that the phosphorylated products which accumulated during the fermentation of galactose are not the esters of this sugar but of glucose and fructose. The hexosediphosphoric ester constituted the major portion of the esterified phosphate. From the monophosphate fraction he was able to isolate trehalosemonophosphate and small amounts of a monophosphate that closely resembled the Robison ester in its properties. Attempts to detect the presence of galactose-phosphate by the methylphenylhydrazine test failed. Perhaps of even greater weight was the fact that he showed that a preparation from adapted yeast, which would ferment galactose, failed to ferment synthetically prepared galactose6-phosphate. On the basis of this evidence, he concludes that galactose-6-phosphate is not an intermediate in the fermentation of galactose by adapted yeast cells. Of further interest is the evidence he presents that the living yeast cell continues to build up the same polysaccharides when galactose is the sole carbohydrate metabolized as when the carbohydrate is glucose. Hydrolysis of these polysaccharides indicated that they are polymerides chiefly of glucose, and to a lesser extent of mannose and fructose.

Kosterlitz ('43) found that galactose-1-phosphate is fermented by extracts of galactose-adapted yeasts. He found further that, although such extracts fermented glucose at higher rates than galactose, the fermentation rates of galactose1-phosphate and glucose-1-phosphate were identical. It must be noted, however, that the fermentation rate of the mono-esters was lower than the corresponding 
ones for the free hexoses. On the basis of the equality of the fermentation rates of mono-phosphate esters, Kosterlitz postulates the existence of the following equilibrium,

$$
\text { Galactose-1-p } \leftrightarrows \text { Glucose-1-p. }
$$

However, the same experimental results (unequal rates for the unphosphorylated hexoses, equal but lower rates for the monophosphates) can be explained if either the phosphotase activity or phosphate acceptance were limiting. This would also explain the lower rate of fermentation rate of the esters.

Kosterlitz, on the basis of his experimental results, proposes the following hypothesis of adaptation to galactose fermentation: the formation of two new enzymes is involved. Enzyme (1) phosphorylates galactose at $C_{1}$ probably by a system similar to the hexokinase-adenylpyrophosphate systems which phosphorylates glucose and fructose at $\mathrm{C}_{6}$ (Meyerhof, '35). Enzyme (2) converts galactose1-phosphate to Robison ester, probably by way of glucose-1-phosphate and subsequent action of phosphoglucomutase or isomerase.

The evidence for the formation of two enzymes stems from the observation that in two out of five samples of dried yeast (Kosterlitz, '43), the yeasts were adapted to ferment glucose-1-phosphate but could not ferment non-phosphorylated galactose.

The bulk of the evidence presented strongly indicates that the adaptive utilization of galactose occurs through the early entrance of the galactose into the glucose metabolic cycle. A non-enzymatic equilibrium (e.g., glucose-1$\mathrm{P} \leftrightarrows$ galactose-1-P) is ruled out by the existence of galactose non-adaptable but glucose-fermenting strains. On the same basis it is clear that the induction period observed in galactose adaptation is not analogous to the lag period observed in glucose fermentation by ordinary yeast brei, which is explained on the basis of a relatively slow accumulation of phosphate esters.

From the studies of the biochemistry of the adapted cell, as well as the stereochemical structure of galactose, it seems most probable that two enzymes at least are formed during the course of the adaptation: One for the phosphorylation of galactose and one for the isomerization of the phosphorylated product into an intermediate of glucose fermentation. In so far as the adaptation is concerned, it would be necessary to postulate that a single substrate can induce the formation of enzymes other than the one for which it is the specific substrate. This, however, raises no real difficulty since, if the enzymes act serially, the product of the first would be the substrate of the second and so on. Thus one substrate could provide a whole series of substrates for a whole series of enzymes.

\section{THE PHYSIOLOGY OF ADAPTATION}

In contrast with the relatively vigorous investigation into the biochemistry of the galactose-adapted cell, little has been reported which elucidates the nature of the preadaptive period and the conditions under which the enzyme activity makes its appearance. Certain facts were, however, established by the earlier work. 
Attempts to obtain adaptation with non-viable cells or with cells whose physiology has been seriously interferred with by various reagents have uniformly met with failure. The sole exception was the report by Abderhalden ('25) that he had obtained adaptation with dried dead yeast cells. This experiment has never been successfully repeated, and his failure to check the possibility that the adaptation may have been due to the growth of a few surviving cells throws some doubt on the validity of his conclusions. Von Euler and Nilsson ('25) claimed that adaptation will not occur when the cells are suspended in ordinary phosphate containing galactose and they maintained that the addition of " $\mathrm{Z}$ " factor was necessary. The earlier experiments of Dienert ('00) contradicted this, since this author did all his experiments with washed cells in ordinary solutions of phosphate.

Our own experience agrees with that of Dienert. All our adaptations were performed with thoroughly washed cells suspended in phosphate solutions of twice-recrystallized galactose. According to these results, the enzyme can be

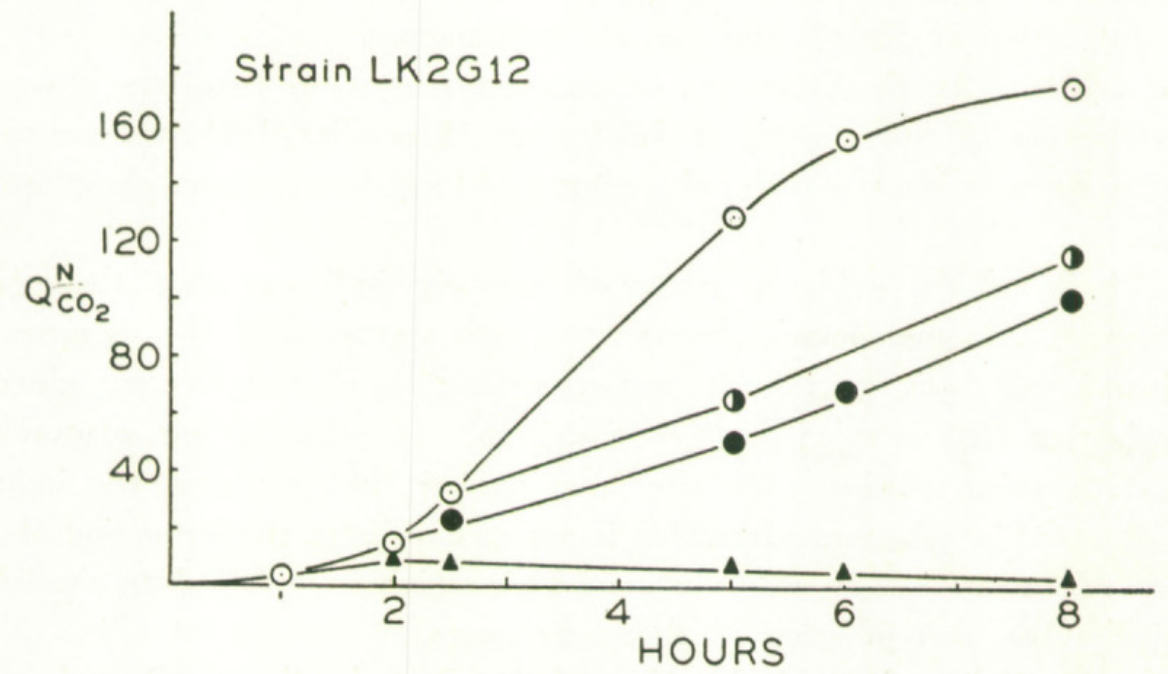

Fig. 2. A test of the ability of cells to increase their galactozymase activity subsequent to aerobic induction periods in contact with galactose. The open circles are the values arrived at for a culture having continuous access to oxygen; the triangles, full-shaded and half-shaded circles represent the subsequent behavior during anaerobiosis.

formed in the absence of an external source of nitrogen. One must conclude, then, that there exists in the cell a source of proteins on which the cell can draw for enzyme formation. It must be noted, however, that the attainable activity level is about half that arrived at if an external source of nitrogen, in the form of ammonium salts or amino acids, is provided (Spiegelman, '45).

Using non-dividing diploid populations, an attempt was made to begin the study of the connection between the synthesis of these enzymes and the over-all metabolism of the cell. Examination of the effect of oxygen (Spiegelman, '45a) revealed that the adaptation was extremely sensitive to oxygen (cf. Stephenson and Yudkin, '36; Schultz, Atkin and Frey, '40). Some strains were found that were completely unable to form galactozymase if they experienced only anaerobic 
contact with galactose, while others could form the enzyme anaerobically. However, the rate of anaerobic adaptation was approximately $1 / 40$ th of that attained in oxygen. In the case of the strains unable to adapt anaerobically, it was of some interest to determine whether enzyme formation could occur at all under anaerobic conditions. This was done by following the activity anaerobically subsequent to brief periods of aerobic incubation with galactose. The results obtained are given in fig. 2. The open circles are values attained during continuous aerobic incubation with 4 per cent galactose. The anaerobic behaviour of the enzyme activity, following various periods of aerobic contact, is represented by the solid triangles and full and half-shaded circles.

It is seen that at the end of the first hour of aerobic contact, the $\mathrm{Q}_{\mathrm{CO}_{2}}^{\mathrm{N}}$ value is about 2.8. Under anaerobic contact there is an initial slight rise above this value and a subsequent slow but consistent drop. At the end of two hours of aerobic contact, the $\mathrm{Q}_{\mathrm{CO}}^{\mathrm{N}}$, attains a value of 15 , and subsequent anaerobiosis does not prevent its increase, although the rate of increase is slower than that obtained in the continual presence of oxygen.

It is clear from these experiments that, while adaptation cannot be initiated anaerobically in these strains, it can proceed under these conditions providing an adequate enzyme activity has been built up. The condition to be met here appears to be that enough enzyme be formed aerobically to utilize the energy content of the galactose molecule when anaerobiosis is established at a rate adequate for further synthesis. We have here the interesting physiological situation where the substrate not only stimulates the formation of an enzyme, but, in addition, acts as the only source of energy for its synthesis. That the energy supply is critical seems clear from two facts. It has been shown (Spiegelman and Nozawa, '45) that for these strains, in common with others (see Stier and Stannard, '35a, b), the endogenous reserves are not fermentable. Further, supplying external fermentable substrate (e. g., fructose and, under certain conditions, glucose) permits (Spiegelman, '45b) the adaptation to take place anaerobically in those strains in which it ordinarily does not occur.

These results suggested that the aerobic adaptation occurred because, under these conditions, the cell could draw on the energy coming from the oxidation of the endogenous reserves for synthetic activity. Experiments were therefore performed to examine adaptation times (time to reach a $\mathrm{Q}_{\mathrm{CO}_{2}}^{\mathrm{N}}$ value of 100 ) when the galactose was added at different levels of the endogenous respiration.

The results on one strain are given in fig. 3 , in which, for purposes of orientation, the endogenous respiration curve is also diagrammed. It is clear from this figure that up to the zero-rate portion of the endogenous curve little difference in adaptation times is encountered. However, the important point to note is that, although adaptation times increase as the galactose is added further out along the zero-rate portion, nevertheless adaptation occurs. These experiments would seem to indicate that adaptation can take place after all the oxidizable reserves have been exhausted and that there is no apparent source of energy. This 

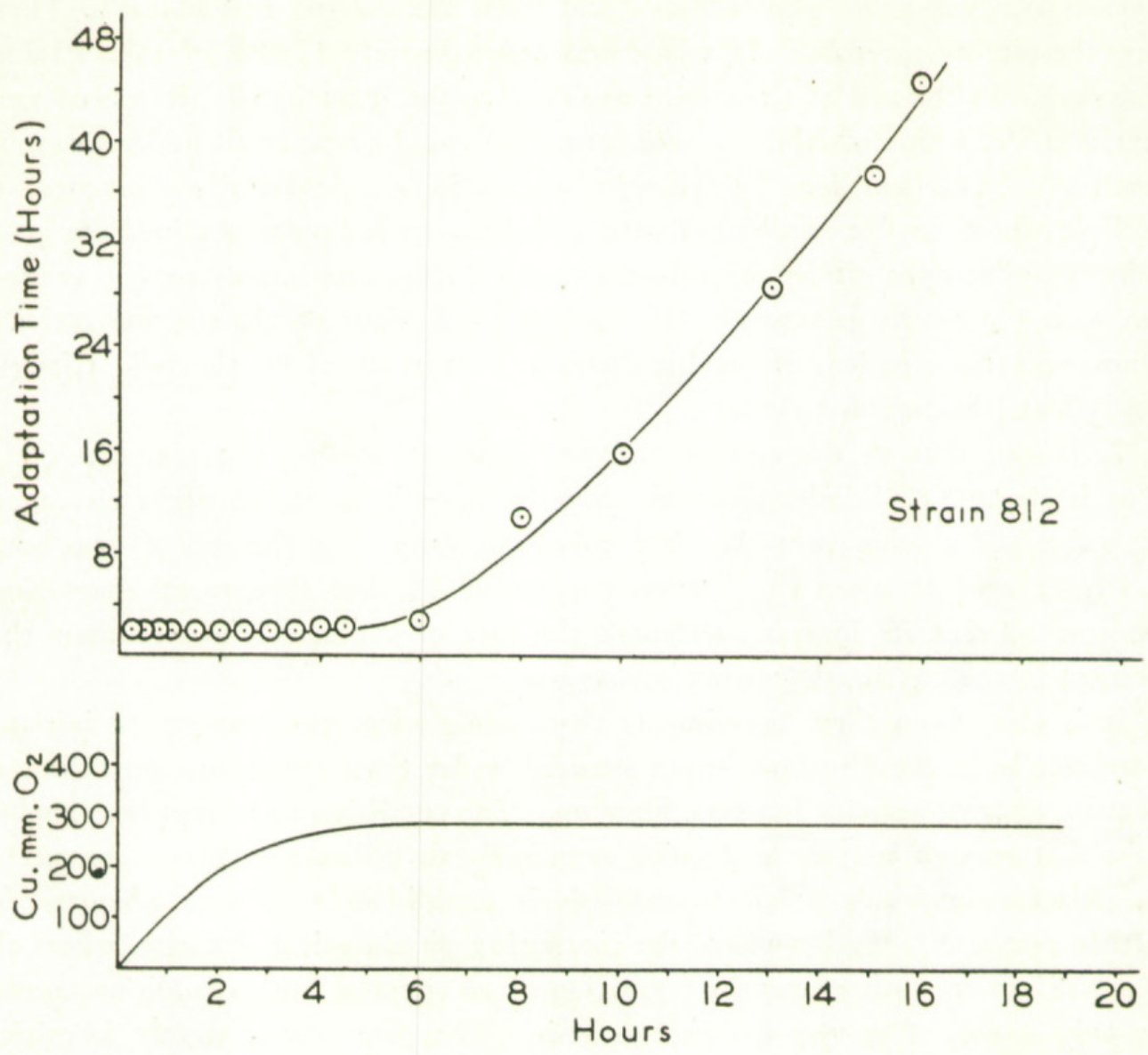

Fig. 3. The effect on adaptation time of adding the galactose at different levels of the endogenous respiration.

situation was, however, clarified by the finding (Spiegelman, '45b) that the galactose itself is oxidized by some enzyme system other than the fermentative one, which forms later under its stimulation.

It is clear from these experiments that the adaptation is intimately connected with the metabolic activity of the cells. Both aerobic and anaerobic processes are equally capable of supplying the energy for synthesis. Further experiments, which will be detailed elsewhere, indicate that agents which interfere with nitrogen assimilation (e. g., azide) completely suppress adaptation.

\section{GENETIC INFERENCES FROM THE KINETICS OF ADAPTATIONS}

It was pointed out in the introduction that, since enzymatic adaptations involved enzyme formation, a careful study of such processes could provide a clue as to the nature of the controls exercised by the genes over the enzyme constitution of cells. The most obvious and easily measured aspect of adaptation is the increase in enzymatic activity observed in non-dividing cells placed in contact with substrate. The usual description of gene action assumes that the gene 
mediates directly the reproduction of the enzyme which it controls. From this point of view, every replication of every enzyme would require the intervention of the appropriate gene. On this basis we would ascribe the increase in enzyme activity, observed in the presence of substrate, to the stabilizing influence of substrate on the enzyme. It is proper to inquire what kind of activity time curve such an hypothesis would predict. We may picture the above mechanism by the following reaction diagram. ${ }^{2}$

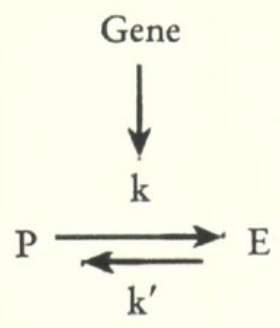

Here $P$ is the immediate precursor (perhaps some indifferent protein) whose transformation yields $E$, the enzyme, the activity of which is being measured. The velocity constant of the transformation from $P$ to $E$ is $k$, and its magnitude is determined by the gene controlling the reaction. The enzyme $E$ is, however, very unstable and reverts to $P$ quickly, the velocity constant of the back reaction being very much larger than that of the forward one. Under such conditions only very small amounts of $E$ would accumulate in the cell. We now assume that substrate $S$ stabilizes $E$ and that in the presence of excess substrate, ES is formed predominantly. This effectively suppresses the value of $k^{\prime}$. In the presence of substrate, the rate of the appearance of enzyme is then described by:

$$
\frac{\mathrm{dE}}{\mathrm{dt}}=\mathrm{k}(\overline{\mathrm{P}}-\mathrm{E})
$$

where $E$ represents the number of units of $P$ transformed into enzyme in unit time and $\overline{\mathrm{P}}$ is the initial amount of precursor present. Integrating and assuming for simplicity that $E$ is zero when $t$ is zero, we find:

$$
\mathrm{E}=\overline{\mathrm{P}}-\overline{\mathrm{P}} \mathrm{e}^{-\mathrm{kt}}
$$

According to equation (3), the assumption that the enzyme is increasing, due to synthesis by the gene and stabilization by substrate, predicts the curve depicted in fig. (4a) as the shape of the activity-time curve during the course of the adaptation. This curve implies that, during the entire period of adaptation, the rate of enzyme synthesis should decrease continuously at any given moment, in a manner proportional to the amount of new enzyme formed at that time. In the

\footnotetext{
${ }^{2}$ It may be noted that this system is a logical analogue of Yudkin's ('38) "mass action" theory of enzyme synthesis.
} 

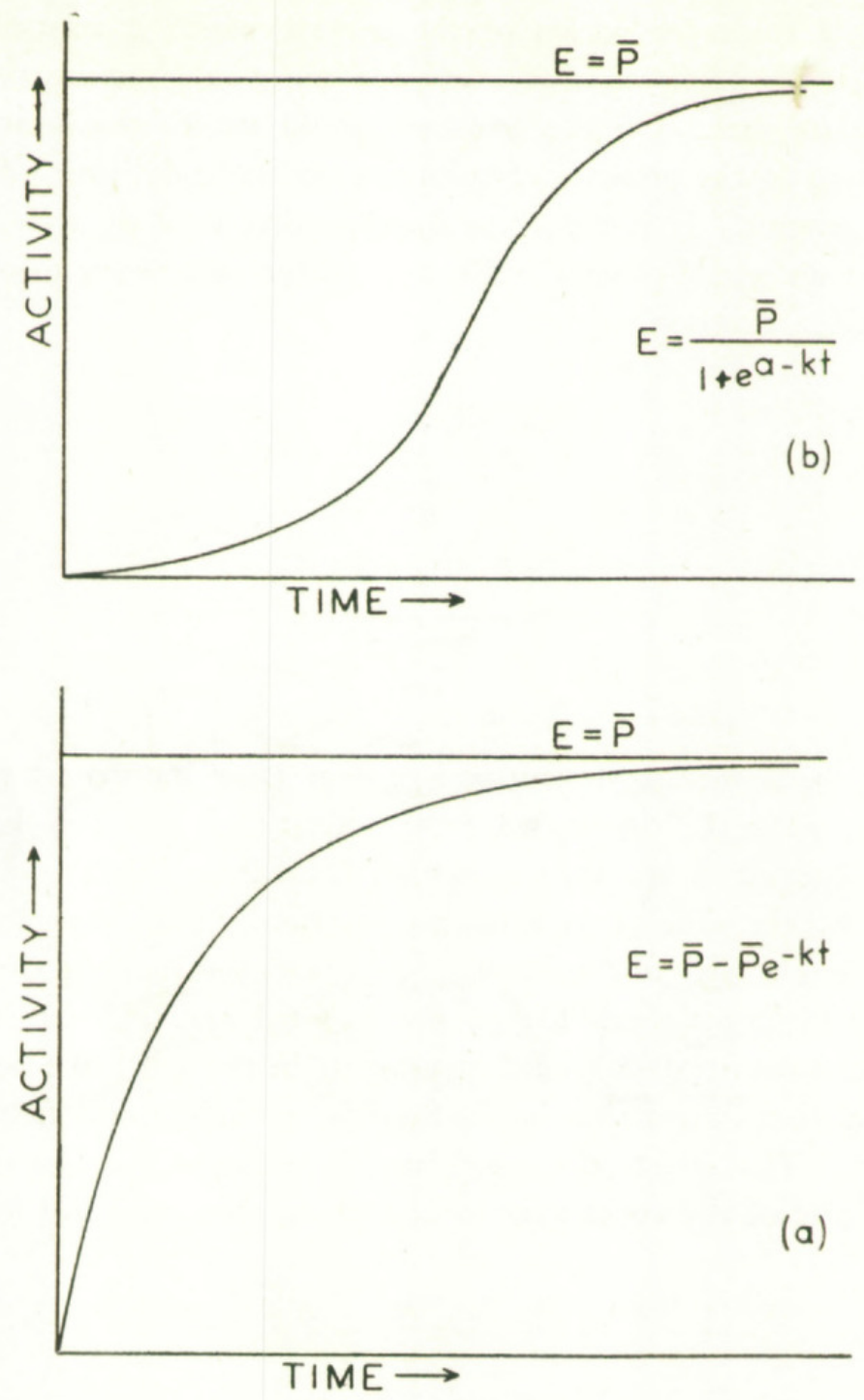

Fig. 4. Activity-time curves predicted by (a) direct primary gene control of enzyme synthesis and (b) self-duplication of enzyme molecules.

course of examining the synthesis of the glucozymase and melibiozymase systems, over 400 adaptation curves have been obtained. In no case does the activity-time curve resemble the course predicted by the above analysis. In all instances (see e. g. fig. 2, open circles) the initial part of the curve is characterized by a rising rate of enzyme formation. This is then followed by a declining rate portion, when presumably the indifferent substrate becomes limiting and finally exhausted.

The increasing rate of enzyme synthesis, with increasing amount of enzyme, suggested an obvious modification of the mechanism detailed in diagram (1). Retaining all the properties ascribed to the first mechanism, we add the additional one that the enzyme once formed can duplicate itself without further need for genic intervention. With this self-duplication hypothesis, instead of reaction diagram (1), we have, 


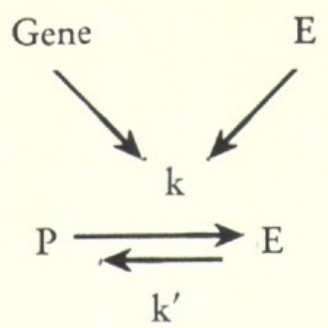

where the symbols have the same meaning. As before, we suppose that the gene can transform $P$ into active enzyme $E$, which is unstable in the absence of substrate. The arrow going from $E$ to $k$ symbolizes the self-duplication of the enzyme, which would express itself in terms of changing velocity constant so that its value at any particular moment would depend on the amount of $E$ present. In the presence of substrate, the rate of formation of the enzyme becomes, under these assumptions, a quadratic function of the amount of enzyme present and takes the form:

$$
\frac{\mathrm{dE}}{\mathrm{dt}}=\mathrm{kE}(\overline{\mathrm{P}}-\mathrm{E})
$$

where $E$ again represents the amount of $P$ transformed into $E$ in unit time and $\overline{\mathrm{P}}$ is the initial amount of precursor present. Integrating equation (5) we obtain

$$
\mathrm{E}=\frac{\overline{\mathrm{P}}}{1+\mathrm{e}^{\mathrm{a}-\mathrm{kt}}}
$$

where $a$ is an integration constant determined by initial conditions. According to equation (5) then, the assumption of self-duplication predicts the s-shaped curve given in fig. $4 \mathrm{~b}$ as the activity-time curve during adaptation.

There is no doubt that the data lend support to the self-duplication hypothesis and rule out the simple genic mechanism underlying reaction diagram (1). More rigorous mathematical and experimental tests have been made and will be detailed elsewhere. An important and critical prediction stemming from the self-duplication mechanism is that, once the process is started, it can proceed in the absence of the gene which initiated it. Attempts to test this prediction were made with data on the inheritance of melibiozymase. The Mendelian mechanism underlying the inheritance of the ability to form melibiozymase was analyzed with the aid of two strains differing in this character.

\section{THE GENETICS OF THE ABILITY TO FORM MELIBIOZYMASE}

Hybrids between melibiose-fermenters and non-fermenters had already been examined by Winge and Laustsen ('39a). All hybrids of such crosses were fer- 
menters, and their results led Winge and Laustsen to state that "the presence of a specific enzyme is dominant to its absence in all the instances studied." They made matings by placing two spores in contact with each other. This method has the disadvantage that one cannot characterize the haplophase parents, since both of the original spores are consumed in the mating. This, and the failure to examine the phenotypes of the segregants from the hybrids, prevented an analysis of the genetic mechanism.

This analysis was undertaken by Lindegren, Spiegelman and Lindegren ('44), using S. carlsbergensis, which could adapt to ferment melibiose, and S. cerevisiae, which could not. In this investigation hybrids were produced by mixing haplophase cultures. Since only part of the culture is needed for the mating, the remainder could be used to determine the characteristics of the parent strain, as well as for back-crossing or mating to other clones of interest. All hybrids formed were allowed to sporulate and the asci dissected to permit examination of the phenotypes of the haploid segregants.

The data obtained from 175 progenies of the interspecific and of related hybrids were consistent with the view that $S$. carlsbergensis contains two pairs of dominant genes $(\mathrm{mel}+)$, either one of which permitted the production of melibiozymase. Since all of the haploid segregants of S. cerevisiae failed to produce the enzyme, it was clear that it was homozygous for the recessive alleles.

\section{SELF-DUPLICATION OF MELIBIOZYMASE IN THE ABSENCE OF ITS GENE}

With the genetics of the capacity to form melibiozymase known, it became possible to devise experiments which would test the self-duplicating hypothesis suggested by the S-shaped adaptation curves. In particular, it was essential to provide answers to the following questions:

(1) If synthesis has been initiated and the gene's allele substituted by segregation, can the substrate-cytoplasmic interaction maintain the enzyme indefinitely in the cytoplasm in the absence of the specific gene?

(2) If some enzyme is present, can synthesis of additional enzyme occur in the absence of the specific gene necessary to initiate its synthesis?

Use was made of progenies of known genetic composition from the S. cerevisiae x S. carlsbergensis pedigree employed in the study of the Mendelian mechanism of melibiozymase inheritance. In the experiments described in the previous section, the cells came into contact with melibiose for the first time in the test for adaptability after segregation had already taken place. To answer the questions posed above, experiments were performed (Spiegelman, Lindegren and Lindegren, '45), in which the matings as well as the segregations were carried out in the presence of melibiose. The results were compared with matings from the same cross in which melibiose was omitted until testing the phenotype of the haploid segregants. To simplify the genetics of the situation, a haplophase clone carrying a single mel+ gene controlling adaptation was used. This was mated to a haplophase clone of S. cerevisiae which carried only the recessive alleles. The heterozy- 
gous diploids so formed were all adaptable and each four-spored ascus from these hybrids yielded two adaptable and two unadaptable haplophase cultures.

TABLE II

EFFECT OF MELIBIOSE ON PHENOTYPIC CHARACTERS OF SEGREGANTS FROM DIPLOIDS FORMED BY MATINGS IN ITS PRESENCE AND ABSENCE

\begin{tabular}{|c|c|c|c|c|c|c|c|c|c|}
\hline \multicolumn{5}{|c|}{$\begin{array}{l}\text { Mating, sporulation and planting } \\
\text { in presence of melibiose }\end{array}$} & \multicolumn{5}{|c|}{$\begin{array}{l}\text { Mating, sporulation and planting } \\
\text { in absence of melibiose }\end{array}$} \\
\hline \multirow{2}{*}{$\begin{array}{l}\text { Ascus } \\
\text { No. }\end{array}$} & \multicolumn{4}{|c|}{ Spores* } & \multirow{2}{*}{$\begin{array}{l}\text { Ascus } \\
\text { No. }\end{array}$} & \multicolumn{4}{|c|}{ Spores* } \\
\hline & A & B & C & $\mathrm{D}$ & & A & B & C & D \\
\hline 1 & + & + & + & + & 8 & + & + & - & - \\
\hline 2 & + & + & + & + & 9 & - & + & - & + \\
\hline 3 & + & + & + & + & 10 & + & + & - & - \\
\hline 4 & + & + & + & + & 11 & + & + & - & - \\
\hline 5 & + & + & + & + & 12 & - & + & - & + \\
\hline 6 & + & + & + & + & 13 & + & - & - & + \\
\hline \multirow[t]{4}{*}{7} & + & + & - & - & 14 & + & + & - & - \\
\hline & & & & & 15 & + & + & - & - \\
\hline & & & & & 16 & + & + & - & - \\
\hline & & & & & 17 & - & - & + & + \\
\hline
\end{tabular}

* + indicates ability to ferment melibiose, - inability. All spores come from a $(+x-)$ cross. See text for further details.

The data obtained on the phenotypes of the haploid segregants from diploids formed and segregated in the presence and absence of melibiose are summarized in Table II. Asci 1-15 originated from the mating of the same pair of mel $+/ \mathrm{mel}-$ haploids, while 16 and 17 originated from mating an equivalent, but not identical, pair of $\mathrm{mel}+/ \mathrm{mel}-$ haploids. Melibiose was present during all stages of the formation and dissection of asci 1-7 inclusive. Asci 10-17 inclusive were formed in the usual way, without melibiose. In handling asci 8 and 9, the agar in which the dissected spores were planted contained melibiose.

It is evident from Table II that all asci formed in the complete absence of melibiose give the typical 1:1 ratio characteristic of a heterozygous hybrid segregating a single pair of genes. On the other hand, with the exception of ascus No. 7 , identical heterozygotes treated with melibiose yielded four adaptable spores from each ascus.

The results obtained in the absence of melibiose prove that only 2 spores from each tetrad in asci 1-6 inclusive contain the specific mel + gene responsible for 
adaptation to fermentation. Despite this, all four spores from these tetrads produced haplophase cultures which fermented melibiose.

Since all steps were carried out in the presence of melibiose, selection of adaptable mutants from haploids originally unable to ferment melibiose might have occurred. Several specific facts, however, rule out this possibility:

During the testing of many haploid segregants from S. cerevisiae, all of which are negative, no mutation to an adaptable type has ever been observed whether melibiose was present or not; (2) the same is true of negative haploids from heterozygous hybrids. No mutation to adaptables in these have been seen no matter how often they have been through melibiose media; (3) asci 8 and 9, whose segregants were planted on melibiose, yielded the standard 1:1 ratio.

Presumably, the cultures from the two spores of each tetrad from the first six asci were able to ferment melibiose only due to the presence of the enzyme in the cytoplasm. On this basis it was to be expected that removal of the melibiose would lead not only to the disappearance of fermentability in all cases, but to an eventual loss of readaptability in two of every four cultures arising from each of the first six asci. To exclude the complication of mutation away from adaptability, non-dividing cultures, suspended in $\mathrm{M} / 15 \mathrm{KH}_{2} \mathrm{PO}_{4}$, were used. Portions of all 24 adapted haplophase cultures originating from the first 6 asci were dissimilated in the absence of substrate until they had lost all melibiozymase activity. Samples were then removed and incubated with melibiose to test for readaptability. Not all haplophase cultures survived this relatively vigorous treatment which in some cases lasted 20 days. Table III summarizes the results obtained with those asci, all four of whose segregants stood the treatment. The removal of the melibiose and its stabilizing influence leads to the disappearance of the enzyme in the cytoplasm and the reappearance of the expected Mendelian ratios.

Data collected at the same time indicate that synthesis of additional enzyme can occur in the absence of the mel + gene. After allowing all suspensions to

TABLE III

READAPTABILITY OF SPORES OBTAINED BY MATINGS

IN PRESENCE OF MELIBIOSE AFTER HAVING LOST ALL ADAPTIVE ENZYMES

\begin{tabular}{|c|c|c|c|c|}
\hline \multirow{2}{*}{$\begin{array}{c}\text { Ascus } \\
\text { No. }\end{array}$} & \multicolumn{4}{|c|}{ Spores* } \\
\hline & A & B & $\mathrm{C}$ & $\mathrm{D}$ \\
\hline 1 & + & - & + & - \\
\hline 2 & - & - & + & + \\
\hline 4 & + & + & - & - \\
\hline 6 & + & + & - & - \\
\hline
\end{tabular}

* + indicates readaptability, - inability. 
fall to low $\mathrm{Q}_{\mathrm{CO}}^{\mathrm{N}}$, values (between 1.8 and 10.1) in the absence of melibiose, portions were removed and incubated with melibiose and regeneration of activity followed at intervals by measuring $\widehat{Q}_{\mathrm{CO}}$. The results of those haploid segregants which subsequently lost the ability to adapt are recorded in Table IV. It is seen that in all cases marked increases in activity were obtained. Furthermore, all the strains listed in Table IV were carried in standard media with melibiose and were tested at weekly intervals. At the end of three months they could all ferment melibiose at rates equal to, or greater than, the original rate. This period is equivalent to over 2,000 cell generations. It is evident that the enzyme can not only maintain itself in the presence of melibiose but it can also increase in absolute amount.

TABLE IV

$\mathrm{Q}_{\mathrm{CO}_{2}}^{\mathrm{N}}$ VALUES AFTER AEROBIC INCUBATION WITH MELIBIOSE OF STRAINS WHICH EVENTUALLY LOST THEIR ABILITY TO ADAPT

\begin{tabular}{|c|c|c|c|c|}
\hline \multirow[b]{2}{*}{ Strain } & \multicolumn{4}{|c|}{ Hours of contact with melibiose } \\
\hline & 0 & 12 & 24 & 48 \\
\hline 1B & 5.1 & 40 & 96 & 123 \\
\hline $1 \mathrm{D}$ & 2.4 & 26 & 109 & 114 \\
\hline $2 \mathrm{~A}$ & 10.1 & 39 & 86 & 136 \\
\hline $2 \mathrm{~B}$ & 6.3 & 46 & 73 & 101 \\
\hline $4 \mathrm{C}$ & 5.0 & 69 & 160 & 170 \\
\hline $4 \mathrm{D}$ & 4.2 & 29 & 91 & 134 \\
\hline $6 \mathrm{C}$ & 1.8 & 34 & 84 & 141 \\
\hline $6 \mathrm{D}$ & 4.8 & 42 & 121 & 130 \\
\hline
\end{tabular}

The simplest explanation which can be offered at present for the above results is the same one advanced for the S-shaped curve, i. e., the effect of substrate on a self-duplicating enzyme. We may thus explain the effects of melibiose on the inheritance of melibiozymase as follows: by performing the mating in the presence of melibiose, the cytoplasm of the haploid carrying the mel+ gene is packed with the melibiose-fermenting enzyme. Since both copulating haploids contribute cytoplasm equally to the zygote it starts out with some enzyme and builds up more since it has the gene also. Since sporulation occurs in the presence of melibiose and since the sporulation period is characterized by growth and considerable storage, the enzyme molecules are stabilized and possibly increased in amount. Each of the four haploid segregants derives its cytoplasm from the diploid hybrid, and it follows that each will have enzyme molecules in its cytoplasm no matter 
what its genetic constitution. Finally, the enzyme molecules are stabilized and duplicate themselves in the descendants of the spores which do not have the mel + gene as long as they are kept in contact with the substrate.

It cannot be denied that explanations of these results involving unstable genes can be devised. It is further recognized that no analysis of the adaptation curves, no matter how rigorously it is formulated and subsequently tested, can ever prove the self-duplication of enzymes. It is impossible to exclude in any finite period all the conceivable modifications which can be advanced containing as their primary postulate the gene as the sole self-duplicating unit in cells. This much, however, may be said in view of the experiments on melibiozymase and galactozymase-such theorizations will not be "pleasingly simple."

We may, therefore, on the basis of the available evidence, suggest that some enzymes are capable of duplicating themselves without genic intervention. In these cases of enzyme formation, the sole function assignable to the gene is the initiation of the enzyme synthesis. This initiation could be effected by virtue of a low but ever-present capacity of the gene to mediate the production of a few enzyme molecules. A mechanism of this kind would keep some enzyme molecules always available in the cytoplasm for autosynthetic activity when substrate is supplied. It would, at the same time, explain the observed Mendelian inheritance of adaptability in the absence of substrate, as well as the ability of substrate when present to obscure the Mendelian ratios during segregation. In addition, it would provide a rational basis for the S-shaped adaptive curves.

The question of how generally the above concept can be applied cannot be decided without further experiments on other enzyme systems. From a casual observation it might seem that self-duplication of the enzymes is inconsistent with the results on dosage effects. It must, however, be noted that in such studies, end products of enzyme activity, rather than enzymes themselves, are being studied. Furthermore, in order for the self-replication capacity of enzymes to express itself, the precursors would have to be initially present in sufficient quantities. If the enzyme precursor is limiting, the effect of $E$ on the forward velocity constants would be negligible, and diagram (4) would transform to diagram (1). Then, even if the enzyme was able to duplicate itself, the synthesis would be predominantly gene-controlled. The addition of another gene would, under such conditions, effect the quantitative level of enzyme activity, To this must be added, in so far as gene-dosage studies are concerned, possible limitations of the precursor to the end product. In this connection, it is of interest to note that competitive interaction for a limited amount of substrate has been assumed in Dr. Stern's theorizations on the nature of gene action.

Finally, it must be noted, from a general physiological point of view, that self-duplication of enzymes provides a degree of physiological flexibility not easily attained with the older, more rigid concepts of gene control over enzymatic constitution. Under this concept the enzymatic composition is dependent not only upon the genome, but also on the available substrates. Enzymes could thus 
increase and decrease in response to the substances placed in their environment. In addition, it provides an experimentally interesting mechanism for cytoplasmic differentiation, since it predicts that cells with the identical genomes need not possess identical enzymatic constitutions.

\section{SUMMARY}

The general problem of enzymatic adaptation is discussed. The view is adopted that adaptive-enzyme formation is a quantitatively exaggerated instance of a more general phenomenon involving the effects of substrates on the synthesis and stability of their enzymes. Experiments on the genetic control of adaptation to the fermentation of galactose and melibiose by yeasts are described and discussed in detail. It is pointed out that these instances, where enzyme formation can be followed with relative ease, offer a unique opportunity for examining the oftenrepeated concept that genes determine phenotype by virtue of their control of the enzymatic constitution of cells. In particular, the extent and mechanism of such control might thus be open to experimental analysis.

A study of the kinetics of the formation of galactozymase and melibiozymase in yeast cells is detailed which suggested that at least in these cases the enzymes were capable of self-duplication without the necessity of genic intervention. The hypothesis of self-duplication led to the prediction that such enzymes, once formed, should maintain themselves and be transferable from one cell generation to the next in the complete absence of their corresponding genes. Experiments on the inheritance of melibiozymase in the presence and absence of melibiose are reported which tend to confirm this prediction. It is suggested that, in these cases of enzyme formation, the sole function assignable to the gene is the initiation of the enzyme synthesis, this initiation being effected by virtue of a low but everpresent capacity of the gene to mediate the reproduction of a few enzyme molecules. Subsequent replication is dominated by the self-duplicating enzyme molecules.

\section{REFERENCES}

Abderhalden, E. (1925). Versuche über den Einfluss der Züchtung von Hefe auf Galaktose auf die Vergärbarkeit dieses Kohlenhydrates durch diese. Fermentforsch. 8:42-55; 474-493.

Armstrong, E. F. (1905). Studies on enzyme action. VII. The mechanism of fermentation. Proc. Roy. Soc. Lond. (B) 76:600-605.

Cattaneo, Carlo (1933). Gewinnung von Phosphoglycerinsäure aus Galaktose und Spaltung von Phosphoglycerinsäure durch Galaktosehefen. Biochem. Zeitschr. 267:456-459.

Colowick, S. P., and Kalckar, H. M. (1941). An activator of the hexokinase system. Jour. Biol. Chem. 137:789-790.

Dienert, F. (1900). Sur la fermentation du galactose et sur l'accutunance des levures à ce sucre. Ann. Inst. Pasteur 14:139-189.

Dubos, R. S. (1940). The adaptive production of enzymes by bacteria. Bact. Rev. 4:1-16.

Epps, H. M. R., and Gale, Ernest F. (1942). The influence of the presence of glucose during growth on the enzymic activities of Escherichia coli. Biochem. Jour. 36:619623.

v. Euler, H., and Jansson, B. (1927). Über die Anpassung von frischen Kulturhefen an Galaktose. Zeitschr. f. Physiol. Chem. 169:226-234. 
- und Nilsson, R. (1925). Über der Galaktosavergärung durch Hefe nach Vorbehandlung mit dieser Zuckerart. Ibid. 143:89-107.

Gale, F. E. (1943). Factors influencing the enzymic activities of bacteria. Bact. Rev. 7:139-173.

Grant, G. A. (1935). The metabolism of galactose. I. Phosphorylation during galactose fermentation and its relation to the interconversion of the hexoses. Biochem. Jour. 29²:1661-1676.

Guilliermond, A. (1903). Recherches sur la germination des spores dans le Saccharomyces Ludwigii (Hansen). Bull. Soc. Myc. de France 19:19-31.

Harden, A., and Norris, R. V. (1910). The fermentation of galactose by yeast and yeastjuice. Proc. Roy. Soc. Lond. (B) 82:645-649.

Karström, H. (1938). Enzymatische Adaptation bei Mikroorganismen. Ergeb. Enzymforsch. 7:350-376.

Kluyver, A. J. (1914). Biochemische suikerbepalingen, proefschrift Delft, p. 91. (Cited by Sohngen and Coolhaas, 1924).

Kosterlitz, H. (1943). The fermentation of galactose and galactose-1-phosphate. Biochem. Jour. 37:322-326.

Kuhn, R. (1923). Über Spezifität der Enzyme. Zeitschr. f. Physiol. Chem. 125:28-92.

Lewis, I. M. (1934). Bacterial variation with some special reference to behavior of some mutable strains of colon bacteria in synthetic media. Jour. Bact. 28:619-638.

Lindegren, C. C., and Lindegren, G. (1943a). Selecting, inbreeding, recombining and hybridizing commercial yeasts. Ibid. 40:405-419. Sci. 29:306-308.

,$-(1943 \mathrm{c})$. Segregation, mutation and copulation in Saccharomyces cerevisiae. Ann. Mo. Bot. Gard. 30:453-464.

, Spiegelman, S., and Lindegren, G. (1944). Mendelian inheritance of an adaptive enzyme. Proc. Nat. Acad. Sci. 30:346-352.

Linderstrom-Lang, K. (1940). Enzymatische Adaptation. Nord-Wiedenhagen, Handbuch der Enzymologie. Akademische Verlagsgesellschaft, Becker u. Erler, Leipzig.

Meyerhof, O., und Lohmann, K. (1927). Über die enzymatische Milchsäurebildung im Muskelextrakt. Biochem. Zeitschr. 185:113-164.

, Hexosediphosphosäure und Dioxyacetonphosphorsäure. Ibid. 271:89-110.

, (1935). Über die Wirkungsweise der Hexokinase. Naturwissenschaften 23: $850-851$.

Nilsson, R. (1943). Über die Organisierung der biochemischen Wirkstoffe in der Zelle. Naturwissenschaften 34:25-35.

Quastel, J. H. (1937). Enzyme formation in bacteria. Enzymologia 2:37-42.

Rahn, O. (1938). On the nature of adaptive enzymes. Growth 2:363-367.

Schultz, A. S., Atkin, L., and Frey, C. N. (1940). Influence of oxygen on the fermentation of maltose and galactose. Jour. Amer. Chem. Soc. 62:2271-2272.

Slator, A. (1908). Studies in fermentation. II. The mechanism of alcoholic fermentation. Ibid. 93:217-235.

Sohngen, N. L., and Coolhaas, C. (1924). The fermentation of galactose by Saccharomyces cerevisiae. Jour. Bact. 9:131-141.

Spiegelman, S. (1945a). The effect of anaerobiosis on adaptive enzyme formation. Jour. Cell. \& Comp. Physiol. (In press).

, (1945b). Unpublished experiments.

, and Lindegren, C. C. (1944). A comparison of the kinetics of enzymatic adaptation in genetically homogeneous and heterogeneous yeast populations. Ann. Mo. Bot. Gard. 31:219-233.

, the haplophase to populational adaptation. Jour. Bact. (In press).

, and Lindegren, G. (1945). Maintenance and increase of genetic character in the absence of the specific gene. Proc. Nat. Acad. Sci. 31:95-102. 


\section{$2 \mathrm{BHL}$ Biodiversity Heritage Library}

Spiegelman, S. 1945. "The Physiology and Genetic Significance of Enzymatic Adaptation." Annals of the Missouri Botanical Garden 32, 139-163.

https://doi.org/10.2307/2394254.

View This Item Online: $\underline{\text { https://www.biodiversitylibrary.org/item/54730 }}$

DOI: https://doi.org/10.2307/2394254

Permalink: https://www.biodiversitylibrary.org/partpdf/16350

\section{Holding Institution}

Missouri Botanical Garden, Peter H. Raven Library

\section{Sponsored by}

Missouri Botanical Garden

\section{Copyright \& Reuse}

Copyright Status: In copyright. Digitized with the permission of the rights holder.

License: http://creativecommons.org/licenses/by-nc-sa/3.0/

Rights: https://biodiversitylibrary.org/permissions

This document was created from content at the Biodiversity Heritage Library, the world's largest open access digital library for biodiversity literature and archives. Visit BHL at https://www.biodiversitylibrary.org. 